\title{
Lesson Study in Blended Setting: Comparative Study on Students' Skills in Producing Educational Electronic Cinema
}

\author{
Luh Putu Putrini Mahadewi, I Made Teguh \\ Universitas Pendidikan Ganesha, Bali, Indonesia \\ e-mail: 1pp-mahadewi@undiksha.ac.id
}

\begin{abstract}
The purposes of the study were: (1) to identify the pattern of lesson study implementation for course that was offered in blended setting, (2) to test the impact of lesson study in blended setting on students' skills in producing educational electronic cinema. During the study, the Lewis Model was used to research the lesson either in face to face or in online classrooms. In addition the roles of observers in online classroom were assigned based on selected online platform. To test the impact of lesson study in blended setting on students' skills in producing educational electronic cinema, the quasi experimental type post-test control group research design was used. Two groups of the student were involved, one as a control group and the other one as an experimental group. The control group was given lesson in blended setting without research lesson and the experimental group was given lesson in blended setting with research lesson. Data collection methods were: observation, interview, questionnaire, documentation and test. Based on the methods, the following instruments were used: observation sheet, interview guidelines, questionnaire sheet, document, and rubric. The collected data were then analysed by using descriptive technique and t-test. Findings of the research are detailed as follows: (1) the pattern of lesson study implementation that was offered in blended setting refers to the design of blended learning that is flipped classroom setting. (2) Lesson study in blended setting brought an impact although not significant on students' skills in producing educational electronic cinema. It is suggested that lesson study should be conducted continuously, not only in face to face course but also in an online course to promote the best aspect of blended learning.
\end{abstract}

Keywords: lesson study, blended learning, students' skills

\section{INTRODUCTION}

Educational Cinematography is one of the core courses in the Department of Educational Technology at Universitas Pendidikan Ganesha. The purpose of this course is to provide the students with knowledge as well as skills needed to produce educational electronic cinema. Considering the amount of concepts and skills that should be mastered by the students in one semester were not supported by appropriate face to face meetings, than this course is offered blended, through face to face and online meetings.

To enhance the quality of instruction in each Department at Faculty of Educational Science including in the Department of Educational Technology, since 2012, lesson study has been implementing continuously. Some of the courses that have been using lesson study to research the lesson are: Multimedia, Entrepreneurship, Textbased Programming. Until now, only one course implements lesson study in blended setting that is Text-based Programming course. The other courses that are offered blended have not yet been investigated. Because of it, there is limited information about lesson study implementation pattern on courses that are offered in blended setting. Thus, the impact of lesson study on students' achievement in taking the blended course is also minimum. Those information are very crucial to improve the quality of instruction that is offered in blended setting and also to promote the existence of lesson study in various learning settings, either in face to face, online course or both. The purposes of the study were: (1) to identify the pattern of lesson study implementation for course that was offered in blended setting, and (2) to test the impact of lesson study in blended setting on students' skills in producing educational electronic cinema.

Research lesson that is known as lesson study was developed in Japan for the first time as program for teacher professional development in improving the learning practice. Lesson study is a systematic steps in building teacher's knowledge and it has shown impact not only to the teachers but also to the students (Lewis in Singtech, 2015). The concept of lesson study is relatively simple. The 
teachers working in group/team in designing the instruction in collaborative way then they observing the instruction together and after the instruction they conducting reflection of what they have been through to improve the next instruction. The focus of lesson study is on instruction in which the students doing their learning activities, not to evaluate teachers' competency in teaching.

There are three important steps of conducting lesson study: (1) plan, teachers in group collaboratively identifying the problem of instruction then designing the instruction, (2) do, implementing the instruction based on the design, and (3) see, evaluating the instruction to revise the design of the next instruction and sharing teachers' experiences and findings to their peers (Mahmudi (2006:2). Lewis (2002) stated that lesson study as continuous method to improve the instruction based on careful observation on students and their activities is a cycle that shows how the teachers are together: (1) formulating the goals of instruction for students and its long term development, (2) planning research lesson collaboratively that is designed to achieve the goals, and (3) implementing research lesson with one teaching tea and the other collect findings from the instruction and its development, (4) discussing the collected findings and using them to improve the instruction.

Blended learning is also known as hybrid learning or mixed learning. Its definition has evolved from time to time. Formerly, blended learning was defined as the integration of various types of learning activities and resources in classroom, laboratory or studio. Currently, blended learning is defined as the integration of classroom learning and online learning. Saliba, Rankine and Cortez (2013) stated that "Blended learning refers to a strategic and systematic approach to combining times and modes of learning, integrating the best aspects of face-to-face and online interactions for each discipline, using appropriate ICTs". Supporting Saliba, Rankine and Cortez, Garrison (2013) defines blended learning as the integration of experiences of face to face and online learning through effective instructional design by using information communication and technology to achieve intended learning experiences.

Blended learning as the integration of the best aspects of face to face and online learning has advantages. According to Marsh (2012) blended learning offers the following advantages: providing more individual learning experiences, providing more personal learning support, enhancing and motivating independent and collaborative instructions, improving students' involvement in learning, accommodating various learning styles of the students, providing a medium to practice skills outside of the classroom, providing environment to practice that can reduce the learning pressure on students, giving time flexibility for the students to study, and facilitating the students to develop prestigious skills needed by $21^{\text {st }}$ century. Blended learning promoting student-cantered instruction that requires the teacher to be focus on students' needs and abilities. The teachers should focus on the design/plan, implementation and the evaluation of instruction that meet with the needs of their students. Students' competency refers to their knowledge, skills, abilities and behaviours on certain subject that support their performance. Washington State Human Resources (2012: pp.1) defines "Competencies are the measurable or observable knowledge, skills, abilities, and behaviors (KSABs) critical to successful job performance". There are three types of competencies: (1) knowledge competencies, theoretical and practical understanding on certain subject; (2) skill and ability competencies, natural capacity or learned to perform an action; and (3) behavioural competencies, patterns of action or behaviour.

Etymologically, competency is defined as "ability that is needed to do or to perform task based on knowledge, skills and working attitude" (Director General of Learning and Student Affairs, 2010/2011: 9). From the etymology definition, then the definition of competency is formulated as follows. "Competency is individual abilities that are observable, including knowledge, skills and working attitude in conducting a certain task based on standard performance that has been established.

Finally, it can be concluded that competency is individual abilities that can be measured/observed including knowledge, skills and working attitude in conducting task. In this research, the competency is refers to students' knowledge, skills and working attitude in producing educational electronic cinema.

\section{METHODS}

The subjects of this research were lecturer who was teaching Educational Cinematography Course and students who were taking Educational Cinematography Course in the Department of Educational Technology, Faculty of Educational Science at Universitas Pendidikan Ganesha. The objects of current research were lesson study implementation in blended learning and students' 
competencies in producing educational electronic cinema.

The data of the research are: (1) the pattern of lesson study implementation in blended learning of Educational Cinematography Course, and (2) data of students' skills in producing educational electronic cinema. Based on the types of the data, the methods used to collect data were: observation, interview, questionnaire and documentation to collect the data of the pattern of lesson study implementation; performance test method to collect the data of students' skills in producing educational electronic cinema.

The collected data were then analysis by the following techniques. The data obtained from observation, interview, questionnaire and documentation methods were analysed by using descriptive qualitative from Miles and Huberman (1994) that consists of three systematic steps: (1) data reduction, (2) data display, and (3) conclusion drawing/verification. The data gathered from performance test method were analysed by using ttest. The students were divided into two groups, one group was assigned as control group and the other group was assigned as experiment group. There was no research lesson for the control group and there was research lesson for the experiment group.

\section{FINDING}

\subsection{The Pattern of Lesson Study Implementation}

The results from observation, interview, questionnaire and documentation showed the following information.

First, the lesson study in blended learning of Educational Electronic Cinema Course was implemented by following the design of the blended course. The blended course was using flipped classroom design in which the course was taking in face to face classroom and outside of the classroom (online).

Second, for blended learning, the lesson study was conducting in both settings, in the face to face classroom and in the online classroom. The cycle for conducting the lesson study in both settings were the same: (1) plan, (2) do, and (3) see.

Third, the different of lesson study implementation between face to face and online learning was on the tools that were used to conduct the lesson study in an online classroom, particularly at the "do" phase. In the face to face classroom, the observers are free to observe the lesson. The same thing happened in the online classroom, observers were assigned as non-editing teachers so that they can observe the lesson online without having a control to edit the learning content or activities.

\subsection{Students' Skills in Producing Educational Electronic Cinema}

The hypothesis tested in the current research was "there is significant impact of lesson study on students' skills in producing educational electronic cinema". The data collected from the performance test showed there was no significant impact of lesson study on students' skills in producing educational electronic cinema (t observation $(1,13)<\mathrm{t}$ table $(1,70)$, at 0,05 significant level).

The result indicated that in both groups there is no significant/meaningful different on students' skills in producing educational electronic cinema between students who were taking course that is offered in blended learning without lesson study and students who were taking blended learning with lesson study. However, the result also showed that the experiment group has a better performance test result than the control group (mean of performance test result from experiment group is 89,3 and mean of performance test result from the control group is $88,7)$. This finding provide a view that lesson study is not directly impacting students' skills in short amount of time. More than that lesson study is a continuous process that requires holistic improvement of instruction by involving teachers, students and other stakeholders that work collaboratively and continuously.

\section{CONCLUSIONS}

Based on the findings and discussion, it can be concluded that: (1) the pattern of lesson study in blended learning refers to the design of the blended learning that is flipped classroom, (2) lesson study in blended setting brought an impact although not significant on students' skills in producing educational electronic cinema.

\section{ACKNOWLEDGEMENTS}

Thank you very much to the Dean of Faculty of Educational Science at Universitas Pendidikan Ganesha, Prof. Dr. Ni Ketut Suarni, 
M.S., Kons. that continuously support the innovation of teaching and learning at The Department of Educational Technology, Faculty of Educational Science at Universitas Pendidikan Ganesha.

\section{REFERENCES}

[1] Director General of Learning and Student Affairs. 2010/2011. Kerangka Kualifikasi Nasional Indonesia: Indonesian Qualification Framework. Jakarta: Indonesia Ministry of Education and Culture.

[2] Lewis, C.C. 2002. Lesson Study: A Handbook for Teacher-Led Improvement of Instruction. (Online),

(www.lessonresearch.net/briefguide.pdf, accessed on March $17^{\text {th }}$ 2015).

[3] Mahmudi, A. 2006. Lesson Study. Paper. Presented on Workshop of Lesson Study for Math and Science Teachers at Jetis Bantul, Yogyakarta, October $12^{\text {th }} 2006$.

[4] Marsh, D. 2012. Blended Learning: Creating Learning Opportunities for Language Learners. New York, USA: Cambridge University Press.

[5] Miles, M.B., \& Huberman, A.M. 1994. Qualitative data analysis: An Expanded Sourcebook (2 ${ }^{\text {nd }}$ ed.). Thousand Oaks, CA: Sage.

[6] Saliba, G., Rankine, L., \& Cortez, H. 2013. Fundamentals of Blended Learning. Australia: University of Western Sydney.

[7] Singteach. 2015. Lesson Study: The Fact Behind It. (Online), (www.singteach.nie.sg/issue32-hottopic/, accessed on March $\left.21^{\text {st }}, 2015\right)$.

[8] Sukmana, A. I W. I. Y., \& Mahadewi, L.P.P. 2016. Implementing Lesson Study through Blended Learning in Programming 1 at Educational Technology Department. Paper Proceeding. Presented at Educational Technology World Conference, Bali, July $31^{\text {st }}$ August $3^{\text {rd }}, 2016$.

[9] Tegeh, I M., \& Mahadewi, L.P.P. 2016. Sinematografi Pendidikan. Singaraja: Universitas Pendidikan Ganesha.

[10] Washington State Human Resources. 2012. Competencies.

(Online), (www.hr.wh.gov/workforcedataandplanning/w orkforceplanning/competencies/pages/default.a spx, accessed on March 21 ${ }^{\text {st }}, 2015$ ). 